\title{
Problems of Shapour River Salinity Rising Over Recent Prolonged Streamflow Reduction Period and Solutions of River Salinity Management: An Originally Freshwater River Intensively Salinized by Natural Salinity Sources
}

Jahanshir Mohammadzadeh-Habili ( $\sim$ jahan_mohamadzadeh@yahoo.com )

Shiraz University School of Agriculture

Davar Khalili

Shiraz University School of Agriculture

Shahrokh Zand-Parsa

Shiraz University School of Agriculture

Abdoreza Sabouki

Institude for Energy and Hydro Technology, Shiraz, Iran

Ali Dindarlou

Persian Gulf University

Jaber Mozaffarizadeh

Shiraz University

\section{Research Article}

Keywords: Natural salinity sources, Streamflow reduction, Shapour river, Damming, Over-utilization, Salinity fluctuation domain

Posted Date: March 22nd, 2021

DOI: https://doi.org/10.21203/rs.3.rs-284006/v1

License: (c) (i) This work is licensed under a Creative Commons Attribution 4.0 International License.

Read Full License 


\section{Abstract}

The Shapour river with catchment area of $4254 \mathrm{~km}^{2}$ is a major river system in southern Iran. While the upstream river flow (the upper Shapour river) is fresh, it becomes extremely salinized at the downstream confluence of Shekastian salty tributary and the entering nearby Boushigan brine spring. The river then passes through the Khesht plain and finally discharges into the Raeisali-Delvari storage dam, which went into operation in 2009. Over the 2006-2019 period, reduced precipitation and over-utilization of freshwater resources resulted in $\sim 72 \%$ streamflow reduction in the Shapour river. Consequently, the ratios of unused salty/brine water of Shekastian tributary and Boushigan spring to fresh-outflow of the upper Shapour river increased by $\sim 3$ times and river salinity fluctuation domain at the Khesht plain inlet dramatically increased from 2.1-4.0 $\mathrm{dS} \mathrm{m}^{-1}$ to $3.7-26.0 \mathrm{dS} \mathrm{m}^{-1}$. It also resulted in disappearance of most river aquatic species and caused major economic damages in the middle Shapour river. On the seasonal time-scale, consecutive processes of salt accumulation during irrigation season of the Khesht plain date orchards and then salt drainage during rainy season have adjusted salinity fluctuation domain from 3.7-26.0 dS $\mathrm{m}^{-1}$ at the plain inlet to $5.2-8.9 \mathrm{dS} \mathrm{m}^{-1}$ at the plain outlet. In the lower Shapour river, storage/mixing of fresh/salty inflow waters in the Raeisali-Delvari reservoir has adjusted strong salinity fluctuation domain from $0.9-10.7 \mathrm{dS} \mathrm{m}^{-1}$ at the reservoir inlet to $3.6-5.5 \mathrm{dS} \mathrm{m}^{-1}$ at the reservoir outlet. Success of the Raeisali-Delvari reservoir for salinity adjustment is due to its suitable location on the Shapour river, by being situated on downstream of all of the main river tributaries with natural saline/fresh sources of water. Therefore, construction of storage dam on proper site in conjunction with controlled freshwater utilization are viewed as effective measures for salinity management of subjected rivers to natural salinity sources.

\section{Introduction}

In addition to water scarcity, salinity of water resources is a major problem in many parts of the world (Hart et al. 1990). Salinity causes yield reduction of agricultural crops, limitation in diversity of crop species, corrosion of water conveyance systems, limitation in biodiversity of both aquatic and riparian species, and increase in costs of drinking water treatment (Miyamoto, 2007; Cañedo-Argüelles et al. 2013; Goto et al. 2015; Cañedo-Argüelles et al. 2016; Morford, 2019). Salinity sources of water resources can be classified into natural and artificial (secondary) sources. Natural sources include saline springs, surface runoff of evaporite formations and passing of river flow across salt domes and evaporite formations (Morford, 2019). Drainage of agricultural fields and wastewater treatment plants, use of salts as deicing agents for roads, and mining activities are also the main artificial salinity sources (Morford, 2019; Cañedo-Argüelles et al. 2013).

River salinization is a global and growing threat. It has important impacts on the goods and services that rivers provide to humans and therefore, it may have high economic costs (Cañedo-Argüelles et al. 2013). For example, salinization of the Ganges river in Bangladesh has resulted in losses of millions of dollars related to crop and industrial machinery damage and has imposed major risks to human health (Mirza, 
1998). Economic models prepared by United States Bureau of Reclamation suggested that salinity contributes to more than 300 million dollars per year in economic damage across the Colorado river basin, with roughly half occurring in the agricultural sector (Borda, 2004).

Salinization of rivers might be amplified by droughts, periods of less than normal precipitation, streamflow reduction, and damming (Cañedo-Argüelles et al. 2013; Jones and van Vliet, 2018; Fakouri et al. 2019; Kitheka, 2019; Jalali et al. 2019). During hydrological drought periods, salinity of rivers in southern USA increases compared to non-drought periods (Jones and van Vliet, 2018). In the Colorado river catchment, periods of greater than normal precipitation corresponded with decreasing river salinity and periods of less than normal precipitation corresponded with increasing river salinity (Tillman et al. 2019). In hot and dry regions, evaporation from reservoir water surface area can increase river salinity at downstream of dam. For example, due to evaporation, outflow salinity of the Amistad International Reservoir, located at the Texas-Mexico border, has been averaging $10 \%$ larger than the inflow salinity (Miyamoto et al. 2006). Comparison between measured long-term salinity data in the monitoring stations along the Colorado river, published by Tillman et al. (2019), indicates that river salinity below the Hoover and Imperial dams are greater than those inflow salinities. For some cases such as Gotvand dam reservoir in southern Iran, dissolution of submerged evaporite formations by stored water in dam reservoir amplified the river salinity at downstream of dam (Gutiérrez and Lizaga 2016; Jalali et al. 2019; Jahangiry Fard et al. 2019). While several studies have addressed the issue of increased river salinity at downstream of dams, it is possible that reservoir of a storage dam could reduce the river salinity fluctuations, as inflow mixes with stored water in dam reservoir (Inosako et al. 2006). As a matter of fact, it appears that investigation of reservoirs as regulators of river flow salinity has not been the focus of previous studies.

Most of the world's subaerial salt exposures are located in the arid and semiarid Zagros Mountains, Iran (Kent, 1979; Bosak et al. 1998). The salt diapirs of Hormuz salt formation and salt and gypsum units of Gachsaran evaporite formation are the main natural salinization sources for surface water and groundwater resources in southern Iran (Aghdam et al. 2012; Zarei et al. 2014; Zarei, 2016; Nekouei et al. 2016; Nekouei and Zarei, 2017; Jalali et al. 2019). The Shapour river is one of the main river systems in southern Iran, subjected to intense salinization by salt exposures of the Hormuz and Gachsaran formations in the Zagros mountains. A major portion of agricultural and drinking water demands for the Fars and Bushehr provinces in southern Iran are supplied by the surface water and groundwater resources of the Shapour river catchment. While the upper Shapour river streamflow is fresh, the middle part of river is strongly salinized by natural salinity sources. Due to high salinity, the streamflow of middle and lower Shapour river is mainly used for irrigation of date, which is a salinity tolerant plant. In recent years (2006-2019), due to prolonged under-normal precipitations and over-utilization of upstream river basin water resources, streamflow quantity/quality of the Shapour river has dramatically decreased.

This research aims to investigate the influence of natural salinity sources, over-utilization of freshwater resources, agricultural drainage and damming on Shapour river salinity during the recent reduced streamflow period (2006-2019). In this respect, the role of the Raeisali-Delvari storage dam is 
investigated as a water quality regulator, intended to improve the quality of the reservoir outflow water. The main focus of this research will be on detailed data analysis, leading to solutions for salinity reduction/adjustment of influenced rivers by natural salinity sources.

\section{Situation And Hydrogeology Of Study Area}

The Shapour river catchment with surface area of $4254 \mathrm{Km}^{2}$, located in a semi-arid climate in the southern parts of the Zagros mountains, southern Iran, is the study area. Situation and geology map of the Shapour river catchment and location of the measurement stations are shown in Fig. 1.

The $220 \mathrm{Km}$ long Shapour river originates from the Sasan spring at the ancient place of TnagehChougan, located at northwest of Kazerun city, Fars province. The river passes through the Kazerun, Khesht and Shabankareh plains, respectively. When exiting from west of the Kazarun plain, the Shapour river reaches Shekastian salty tributary with catchment area of $625 \mathrm{Km}^{2}$. At $1.7 \mathrm{Km}$ downstream of Shekastian confluence, the Shapour river reaches Boushigan brine spring and then passes through the Khesht plain. After passing through confluences of the Malicheh brackish tributary (catchment area of $303 \mathrm{Km}^{2}$ ), Charbisheh fresh tributary (catchment area of $235 \mathrm{Km}^{2}$ ), and Tanbakoukar fresh tributary (catchment area of $313 \mathrm{Km}^{2}$ ), the Shapour river enters Shabankareh plain in Boushehr province. In 1995, the Raeisali-Delvari storage dam with $685 \mathrm{MCM}$ storage capacity went into construction in the Shapour river as a multi-purpose dam, intended for water resources management, flood control, and salinity adjustment. Dam structure was completed in 2007 and actual reservoir operation was initiated in autumn 2009.

The geological formations in the Shapour river catchment in ascending stratigraphic order are: Hormuz salt, llam-Sarvak limestone, Pabdeh-Gourpi marl, shale and limestone, Asmari limestone, Gachsaran salt, gypsum, and marl, Mishan marl, shale and limestone, Aghajari sandstone and marl, Lahbari flood-plain deposits, Bakhtiari conglomerate, and Quaternary alluvial deposits. Among these formations, llamSarvak, Asmari, Bakhtiari, and Quaternary deposits are important from the perspective of development of fresh groundwater resources, mainly located on east side of river catchment. The outcrop of the Gachsaran formation is the most extended formation in the study area and along with two diapirs of Hormuz salt formation are the main natural salinity sources for quality degradation of the Shapour river.

There are 6 discharge and salinity measurement stations in the study area, identified by symbols $S 1$ to $S 6$ on Fig. 1. Except for station S2, other stations are located on the Shapour river. Stations S1 (outlet of the upper Shapour), S2 (outlet of the Shekastian salty tributary), S4 (outlet of the Khesht plain), and S6 (outlet of dam reservoir) are hydrometric stations. In stations S3 (inlet of the Kheshat plain) and S5 (inlet of dam reservoir), discharge and salinity of the Shapour river has monthly been measured for some years.

In the study area, Shekastian salty tributary, Boushigan brine spring, and Malicheh brackish tributary are the permanent natural salinity sources for the Shapour river. Surface runoff of Gachsaran and Hormoz 
formations are non-permanent salinity sources for the Shapour river. Additionally, evaporation from stored water in the Raeisali-Delvari reservoir is a salinity source for the Shapour river below the dam.

Discharge and salinity of Shekastian and Malicheh tributaries are highly variable and dependent on seasonal and annual variability in precipitation. In contrast, discharge and salinity of Boushigan brine spring are approximately constant values and are not influenced by seasonal or annual precipitation variability. Based on field measurements, discharge and salt concentration values of the Boushigan brine spring are respectively $\sim 11 \mathrm{I} \mathrm{s}^{-1}$ and $\sim 250 \mathrm{~g} \mathrm{~s}^{-1}$.

The oldest rain gauge station in the study area was installed in 1971 at a close distance to the confluence of Shekastian salty tributary with the Shapour river. Using measured precipitation data in this rain gauge station, variation in annual precipitation in the Shapour river catchment is plotted for the 1971-2019 period (Fig. 2). As shown, the average annual precipitation is $452 \mathrm{~mm}$. Additionally, during the prolonged time period of 2006-2007 to 2017-2018 water year, annual precipitation values of the study area are below average, except for 2012-2013 water year.

\section{Results And Discussions}

To identify time range and intensity of the Shapour river streamflow reduction period, variation in river annual outflow volume at hydrometric stations of S1 (outlet of the upper Shapour river), S4 (middle of middle Shapour river), and S6 (inlet of lower Shapour river) are plotted in Fig. 3. As it can be seen, an unprecedented common streamflow reduction period in the three hydrometric stations was initiated in 2006 and is to be continued. Based on this common variation, average of annual river outflow volume at hydrometric stations were separately calculated for two different time ranges before and after 2006. The results were then plotted in Fig. 3 as the average line. Compared to the period prior to 2006, average annual outflow volume of the Shapour river at stations S1, S4 and S6 decreased by 69,74 , and 74\%, respectively. Overall, streamflow of the Shapour river decreased by about $72 \%$. Below normal annual precipitations of 2006 to 2018 and over-utilization of river catchment water resources during the same period are the main reasons for sharp decrease in streamflow of the Shapour river in recent years.

In order to illustrate the over-utilization of the upper Shapour river freshwaters resources, image of extensive water removal from the upstream Shapour river (Sasan spring) by water trucks is shown in Fig. 4.

To illustrate the influence of recent prolonged streamflow reduction period on Shapour river salinity, mean annual discharge and salinity variation in hydrometric stations of the Shapour river catchment (stations S1, S2, S4, and S6) are shown in Fig. 5.

It follows from Fig. 5 that depending on the annual mean discharge value, salinity of the Shekastian salty tributary (station S2) has been fluctuating around the average value of $10.03 \mathrm{dS} \mathrm{m}^{-1}$. Additionally, longterm variability is not observed in salinity data of this tributary. Before initiation of reduced streamflow period in 2006, Shapour river salinity levels at stations S1, S4 and S6 had been fluctuating around 
average values of $\sim 0.80, \sim 3.18$, and $3.76 \mathrm{dS} \mathrm{m}^{-1}$, respectively. Compared to the period prior to streamflow reduction, average value of river salinity at station S1 increased by $20 \%$ and reached the value of $\sim 0.96 \mathrm{dS} \mathrm{m}^{-1}$. River salinity at station S4 substantially increased over the streamflow reduction period, and during the 2017-2018 water year reached the maximum value of $~ 7.08 \mathrm{dS} \mathrm{m}^{-1}(122 \%$ increase compared to prior to streamflow reduction period). Over the three initial years of streamflow reduction, river salinity at station S6 (downstream of dam) showed sharp increasing trend and during the 2008-2009 water year reached the maximum value of $6.90 \mathrm{dS} \mathrm{m}^{-1}$ (82\% increase compared to prior to streamflow reduction period). At the 4th year of low streamflow period, river salinity at station $\mathrm{S} 6$ sharply dropped and was then stabilized at the average value of $4.69 \mathrm{dS} \mathrm{m}^{-1}$, which is only $25 \%$ larger than that of pre-streamflow reduction period.

As Fig. 5 shows, salinity variation among the hydrometric stations of the Shapour river catchment are quite different. The reasons for differences are discussed next. The Shekastian salty tributary catchment is mountainous and its water resources have not been utilized. Therefore, due to lack of human intervention, tributary salinity was not nearly influenced over time. In contrast, agricultural and municipal sectors in the upper Shapour river catchment were in a developing stage, causing increase in drainage water. While freshwater resources decreased due to low precipitation and over-utilization, the drainage water of developing agricultural and municipal sectors of the upper Shapour increased and consequently, the upper Shapour river salinity was intensified by 20\%. For stations S4 and S6, trend of salinity fluctuation is strongly dependent on the operational schemes of the Shapour river water resources. As previously mentioned, most of freshwater resources of the Shapour river catchment are located above station S1. Due to water scarcity over the reduced streamflow period, water resources were over-utilized by means of water wells and direct water removal from river and springs. Consequently, freshwater flow of the Shapour river at station S1 was sharply decreased. In contrast, due to salinity, Boushigan brine spring and Shekastian salty tributary were not used. To show unbalanced utilization of water resources of Shapour river catchment, annual variation in the ratio of salty/brine outflow from Shakastian tributary and Boushigan spring to fresh-outflow from the Shapour river at station S1 are shown in Fig. 6. It is noted that due to constant discharge of $\sim 11 \mathrm{I} \mathrm{s}^{-1}$, annual outflow volume from the Boushigan brine spring was calculated as the constant value of $\sim 0.35 \mathrm{MCM}$. As shown in Fig. 6, ratio of Shakastian salty tributary outflow to the Shapour river fresh-outflow increased from $16.34 \%$ over $1990-2009$ to $44.48 \%$ over $2009-$ 2019 (approximately 3 times rising). Additionally, ratio of Boushigan brine spring outflow to the Shapour river fresh-outflow increased from $0.13 \%$ over $1990-2007$ to $0.45 \%$ over $2007-2019$ (more than 3 times rising). Therefore, $\sim 3$ times increase in the ratios of salty/brine outflow of Shekastian tributary and Boushigan spring to fresh-outflow of the Shapour river was the main reason for sharp increase in river salinity at station S4. Furthermore, $\sim 20 \%$ rising in the Shapour river salinity at station S1 was influential on river salinity rising at station $\mathrm{S} 4$.

Annual fluctuation in Shapour river salinity at downstream of dam can be justified by calculation of longterm variability in the quota of relatively freshwater resources between stations S4 and S6 from the Shapour river flow. The mountainous nature of the catchment area between stations S4 and S6 has 
made it unsuitable for agricultural practices, and so it has mostly remained out of human reach. Except for Malicheh brackish tributary, other contributing water resources below station S4 act as the salinity dilutor for salty outflow water from station S4. Figure 7 shows annual variations in the ratio of water resources entering the Shapour river reach between stations S4 and S6 to the river outflow at station S6. Prior to dam operation, increased water into the Shapour river at the reach between stations S4 and S6 was calculated as the difference between the annual Shapour river outflows at stations S4 and S6. After that, it was calculated by subtracting the annual Shapour river outflow at station S4 from annual inflow water into the reservoir.

As it can be seen from Fig. 7, the average value of the ratio of increased water into the Shapour river from water resources between stations S4 and S6 to the Shapour river outflow at station S6 increased from $28.35 \%$ for the $1982-2009$ period to $54.46 \%$ over the $2009-2019$ period. While Shapour river outflow at station S4 was strongly decreased due to over-utilization of upstream water resources for irrigation and drinking purposes, water resources between stations S4 and S6 were not used. It resulted in $\sim 2$ times rising in the quota of fairly freshwater resources between stations S4 to S6 from the Shapour river flow and consequently, in Shapour river salinity reduction and stabilization below dam during 2009-2019. However, during the 2009-2019 period, some of river salinity rising at station S6 is due to surface evaporation from stored water in the reservoir. Based on measured daily pan evaporation data and daily reservoir water surface area, an average value of $12 \%$ of the reservoir inflow was lost through surface evaporation, contributing to an average increase of $12 \%$ in river salinity below the dam. Overall, Figs. 6 and 7 indicate that influence of the unbalanced utilization of water resources of the Shapour river catchment on the river flow was appeared from 2009-2010 water year.

For the Khesht plain inlet (station S3), limited but useful salinity and discharge data of the Shapour river is available for 1982-1985 (prior to the streamflow reduction period) and 2016-2019 (over the streamflow reduction period). Using this data, salinity and discharge data at the Khesht plain inlet and outlet (stations S3 and S4) are compared in Fig. 8. Before the streamflow reduction period, the Shapour river provided inflow into the Khesht plain all year long. During 1982-1985, continuous release of the Khesht plain drainage water into the Shapour river increased mean river salinity (variability domain), respectively from 2.85 (2.1-4.0) dS $\mathrm{m}^{-1}$ at the Khesht plain inlet to 3.35 (2.5-4.6) dS $\mathrm{m}^{-1}$ at the Khesht plain outlet. During dry seasons of recent streamflow reduction period, the entire discharge of the Shapour river was usually diverted at the Khesht plain inlet for irrigation of date orchards, leading to drying of the Shapour river inside the Khesht plain and consequently, salt accumulation on irrigated lands. However, due to continuous release of excess outflow of the Khesht plain aquifer at station S4, the Shapour river below the Khesht plain has been able to avoid going dry. During peak discharge periods, river flow accompanied by rainfall events would move inside the Khesht plain and the accumulated salt in irrigated lands are washed back into the river system. Therefore, during the recent streamflow reduction period, consecutive processes of salt accumulation and salt washing resulted in river salinity regulation at the Khesht plain outlet. So far, strong salinity fluctuation domain of the Shapour river has been adjusted from 3.7-26.0 dS m-1 at the Khesht plain inlet to 5.3-8.6 dS m-1 at the Khesht plain outlet. 
Based on presented data in Fig. 8, mean river salinity at the Khesht plain inlet showed sharp increase from $~ 2.85 \mathrm{dS} \mathrm{m}^{-1}$ over 1982-1985 to $~ 6.7 \mathrm{dS} \mathrm{m}^{-1}$ over 2016-2019 (139\% rise). At the Khesht plain outlet, mean salinity increased from $\sim 3.35$ to $\sim 6.5 \mathrm{dS} \mathrm{m}^{-1}$ (97\% rise). Smaller river salinity increase at the Khesht plain outlet indicates salt accumulation in the soil profile and groundwater of the Khesht plain, due to using salty water of Shapour river for irrigation.

To investigate the influence of the Raesiali-Delvari storage dam on the Shapour river salinity, measured river discharge and salinity values at the reservoir inlet and outlet (stations S5 and S6) are compared in Fig. 9. It is noted that during the period of data availability at the reservoir inlet (station S5), Shapour river salinity at station S4 was fluctuating between 4.8 to $8.6 \mathrm{dS} \mathrm{m}^{-1}$.

It follows from Fig. 9 that the strong Shapour river salinity fluctuation of $0.9-10.7 \mathrm{dS} \mathrm{m}^{-1}$ at reservoir inlet (station S5) was adjusted to $3.6-5.5 \mathrm{dS} \mathrm{m}^{-1}$ at reservoir outlet (station S6), which is attributed to annual mixing of stored water in the reservoir. Compared to station S4, the higher salinity fluctuation of the Shapour river at station S5 is due to discharge from the Malicheh brackish tributary, located between stations S4 and S5. Despite 12\% salinity rise due to surface evaporation from dam reservoir, mean river salinity below the dam $\left(4.5 \mathrm{dS} \mathrm{m}^{-1}\right)$ is $~ 13.5 \%$ smaller than that of observed above the dam $\left(5.2 \mathrm{dS} \mathrm{m}^{-}\right.$ $\left.{ }^{1}\right)$. Dilution of stored water in the reservoir is the direct result of freshwater discharge by Tanbakoukar tributary and also direct precipitation over the lake area in the reservoir.

Due to density flow, the more saline inflows of reservoirs usually accumulate on the reservoir bottom levels. Considering abundance of saline water inflows into the Raeisali-Delvari reservoir (Fig. 9), stability of reservoir salinity and thermal stratification and consequently, reservoir eutrophication would be possible. To check the possibility of reservoir stability in the Raeisali-Delvari dam, vertical variability of temperature and salinity of stored water in the reservoir were measured at two different times, i.e., 15-Jul2017 and 21-Jan-2018, as shown in Fig. 10. The date of the 2nd measurement coincided with the occurrence of maximum salinity in the Shapour river upstream of the dam.

As Fig. 10 shows, stratification and mixing in the Raeisali-Delvari reservoir respectively occurred on 15Jul-2017 and 21-Jan-2018. At the time of reservoir stratification, salinity increased from $4.42 \mathrm{dS} \mathrm{m}^{-1}$ at reservoir surface to $\sim 4.75 \mathrm{dS} \mathrm{m}^{-1}$ at reservoir hypolimnion layer. Also, the temperature decreased from $38.2^{\circ} \mathrm{C}$ at reservoir surface to $\sim 18.5^{\circ} \mathrm{C}$ at reservoir hypolimnion layer. At the time of reservoir mixing, salinity and temperature along the depth of stored water in the reservoir remained constant at $\sim 4.88 \mathrm{dS}$ $\mathrm{m}^{-1}$ and $\sim 17.7^{\circ} \mathrm{C}$, respectively. Therefore, despite plentiful saline inflows, the Raeisali-Delvari reservoir was not subjected to stability of reservoir stratification. Annual cycle of reservoir stratification and mixing confirms the fact that annual mixing of stored water in the Raeisali-Delvari reservoir is the main reason for salinity adjustment of the Shapour river in the reservoir downstream location.

The semi-arid climatic conditions of the Shapour river catchment have made it suitable for date farming. Based on classifications presented by Maas and Hoffman (1977) and Maas (1993), date is a salt tolerant plant with threshold salinity (i.e., salinity at initial yield decline) of $4 \mathrm{dS} \mathrm{m}^{-1}$ and $3.6 \%$ yield reduction per 
unit increase in salinity beyond threshold. Over the years, Shapour river salinity downstream of station S1 (below Shekastian salty tributary confluence) has always been a major problem and consequently, date farming has been the dominant agricultural crop in the middle and the lower Shapour river. As previously shown in Fig. 8, over the recent streamflow reduction period, Shapour river salinity at the Khesht plain inlet reached the maximum value of $26.0 \mathrm{dS} \mathrm{m}^{-1}$. Consequently, production of irrigated date orchards in the Khesht plain has decreased in terms of quantity and quality. Several date orchards have also become abandoned because of increase in salinity of irrigation water. For example, an image of the abandoned date orchards in the Khesht plain is shown in Fig. 11. In addition to salinity damages to the date orchards of the Khesht plain, the Shapour river water diversion and distribution facilities in the Khesht plain have also been damaged by being subjected to corrosion and destruction by river salinity (Fig. 12).

Based on the results of present study, Shapour river streamflow quality from confluence of Shekastian salty tributary to the Raeisali-Delvari reservoir inlet is in the worst condition in terms of the mean value and fluctuation domain of salinity. Field observations over the recent streamflow reduction period indicated that approximately all of the aquatic species of the Shapour river at the above-mentioned reach have disappeared due to intense river salinity. Additionally, river water has not been suitable for riparian species, domestic animals, and irrigation of most of crop species. Therefore, the most severe economic costs and environmental damages of salinity rising occurred in the middle portion of Shapour river. Despite up to $140 \%$ mean salinity rising and strong river salinity fluctuation in the middle Shapour, river salinity below the dam (lower Shapour river) is less intensified by recent streamflow reduction period. So far, salinity at the worst year of river salinity (2017-2018 water year) has been exceeded by as much as twice units of the threshold salinity value for date tree. Consequently, production quantity and quality of date orchards on downstream of the dam have minimally been influenced by river salinity rising. Minimal damage caused by river salinity rising below the dam can be attributed to river salinity adjustment by annual mixing in the Raeisali-Delvari reservoir and reservoir water dilution by unused fairly freshwater resources between the Khesht plain outlet and the dam site. Success of the Raeisali-Delvari storage dam for salinity management of the Shapour river is due to its suitable location on the Shapour river, by being situated downstream of all of the main river tributaries with natural saline/fresh sources of water. Therefore, the reservoir can collect and mix all entering waters and by acting as a regulator, can produce large volume of water of reasonable quality.

\section{Conclusions}

River salinity rising over prolonged streamflow reduction periods is a major challenge for freshwater rivers by being subjected to natural salinity sources. Over the streamflow reduction periods, salinity of rivers with natural salinity sources are intensified by several parameters, including unbalanced use of river fresh/saline water resources, drainage water of irrigated agricultural fields with river water, and damming. Based on the findings of present research, over-utilization of river freshwater resources during a streamflow reduction period was the main cause of dramatic rise in river salinity, due to increased ratio of saline waters to freshwaters. On the seasonal time-scale, drainage water of irrigated agricultural fields 
along with river flow could adjust river salinity fluctuation by consecutive processes of salt accumulation during the irrigation season and then salt drainage during rainy seasons. Annual mixing of stored water inside the reservoir can result in adjustment of strong river salinity fluctuation domain. Therefore, construction of storage dam on downstream of subjected rivers to natural salinity sources along with minimal utilization of fresh water resources in the upstream catchment can sharply decrease river mean salinity and its fluctuation domain and consequently, providing more water of reasonable quality.

\section{Declarations}

This work was supported by the Iran Water Resources Management Company (IR), Regional Water Company of Fars [Grant number: FAW-97002]. The authors declare that they have no known competing financial interests or personal relationships that could have appeared to influence the work reported in this paper.

\section{Acknowledgements}

The authors deeply thank the Regional Water Company of Fars and the Regional Water Company of Boushehr for providing required data of present study.

\section{References}

1. Aghdam JA, Zare M, Capaccioni B, Raeisi E, Forti P (2012) The Karun River waters in the Ambal ridge region (Zagros mountain range, southwestern Iran): mixing calculation and hydrogeological implications. Carbonates Evaporites 27:251-267

2. Borda C (2004) Economic impacts from salinity in the lower Colorado river basin. Technical Memorandum Number EC-04-02. United States Bureau of Reclamation, Denver

3. Bosak P, Jaros J, Spudil J, Sulovsky P, Vaclavek V (1998) Salt plugs in the eastern Zagros, Iran: results of regional reconnaissance. GeoLines 7:3-174

4. Cañedo-Argüelles M, Kefford BJ, Piscart C, Prat N, Schäfer RB, Schulz CJ (2013) Salinisation of rivers: an urgent ecological issue. Environ Pollut 173:157-167

5. Cañedo-Argüelles M, Hawkins CP, Kefford BJ, Schäfer RB, Dyack BJ, Brucet S, Buchwalter D, Dunlop J, Fror O, Lazorchak J, Coring E, Fernandex HR, Goodfellow W, Achem G, Hatfield-Dodds AL, Karimov S, Mensah BK, Olson P, Piscart JR, Prat C, Ponsa N, Schulz S, C.J., and Timpano AJ (2016) Saving freshwater from salts. Science 351(6276):914-916

6. Fakouri B, Mazaheri M, Mohammadvali Samani J (2019) Management scenarios methodology for salinity control in rivers (case study: Karoon river, Iran). Journal of Water Supply: Research Technology-Aqua 68(1):74-86

7. Goto K, Goto T, Nmor JC, Minematsu K, Gotoh K (2015) Evaluating salinity damage to crops through satellite data analysis: application to typhoon affected areas of southern Japan. Nat Hazards 
$75: 2815-2828$

8. Gutiérrez F, Lizaga I (2016) Sinkholes, collapse structures and large landslides in an active salt dome submerged by a reservoir: The unique case of the Ambal ridge in the Karun river, Zagros Mountains, Iran. Geomorphology 254:88-103

9. Hart BT, Bailey P, Edwards R, Hortle K, James K, McMahon A, Meredicth C, Swadling K (1990) Effects of salinity on river, stream and wetland ecosystems in Victoria, Australia. Water Res 24(9):11031117

10. Inosako K, Yuan F, Miyamoto S (2006) Simple methods for estimating outflow salinity from inflow and reservoir storage. Agric Water Manag 82:411-420

11. Jalali L, Zarei M, Gutiérrez F (2019) Salinization of reservoirs in regions with exposed evaporites. The unique case of upper Gotvand dam, Iran. Water Res 157:587-599

12. Jahangiry Fard M, Amanipoor H, BattalebLooie S, Ghanemi K (2019) Evaluation of effect factors on water quality of Karun river in downstream and lake of the GotvandeOlya dam (SW Iran). Applied Water Science 9:161

13. Jones E, van Vliet MTH (2018) Drought impacts on river salinity in the southern US: implications for water scarcity. Sci Total Environ 644:844-853

14. Kent PE (1979) The emergent Hormuz salt plugs of southern Iran. J Pet Geol 2:117-144

15. Kitheka JU (2019) Salinity and salt fluxes in a polluted tropical river: The case study of the Athi river in Kenya. Journal of Hydrology: Regional Studies 24:100614

16. Maas EV (1993) Testing crops for salinity tolerance. In Proceedings of Workshop on Adaptation of Plants to Soil Stresses, 234-247 (Eds B.V. Baligar, R. R. Duncan and J.M. Yohe). INTSORMIL Publ. No. 94-2. Lincoln, NE: University of Nebraska

17. Maas EV, Hoffman M (1977) Crop salt tolerance-current assessment. Journal of the Irrigation Drainage Division (ASCE) 103(IR2):115-134

18. Miyamoto S, Yuan F, Anand S (2006) Influence of tributaries on salinity of Amistad Reservoir. Texas A\&M University Agricultural Research Center at El Paso. Texas Water Resources Institute, Technical Report No 292

19. Miyamoto S, Yuan F, Anand S (2007) Water balance, salt loading, and salinity control options of Red Bluff reservoir, Texas. Texas A\&M University Agricultural Research Center at El Paso. Texas Water Resources Institute, Technical Report No 298

20. Mirza MMQ (1998) Diversion of the Ganges water at Farakka and its effects on salinity in Bangladesh. Environ Manage 22(5):711-722

21. Morford S (2019) Salinity in the Colorado River Basin. https://watershed.ucdavis.edu/education/classes/files/content/page/6\%20MorfordColorado_Basin_Salinity.pdf

22. Nekouei E, Zarei M (2017) Karst hydrogeology of Karmustadj salt diapir, southern Iran. Carbonates Evaporites 32:315-323 
23. Nekouei E, Zarei M, Raeisi E (2016) The influence of diapir brine on groundwater quality of surrounding aquifers, Larestan, Iran. Environ Earth Sci 75:571

24. Tillman FD, Coes AL, Anning DW, Mason JP, Coplen TB (2019) Investigation of recent decadal-scale cyclical fluctuations in salinity in the lower Colorado River. J Environ Manage 235:442-452

25. Zarei M (2016) Factors governing the impact of emerged salt diapirs on water resources. Ground Water 54(3):354-362

26. Zarei M, Sedehi F, Raeisi E (2014) Hydrogeochemical characterization of major factors affecting the quality of groundwater in southern Iran, Janah Plain. Chem Erde 74:671-680

\section{Figures}




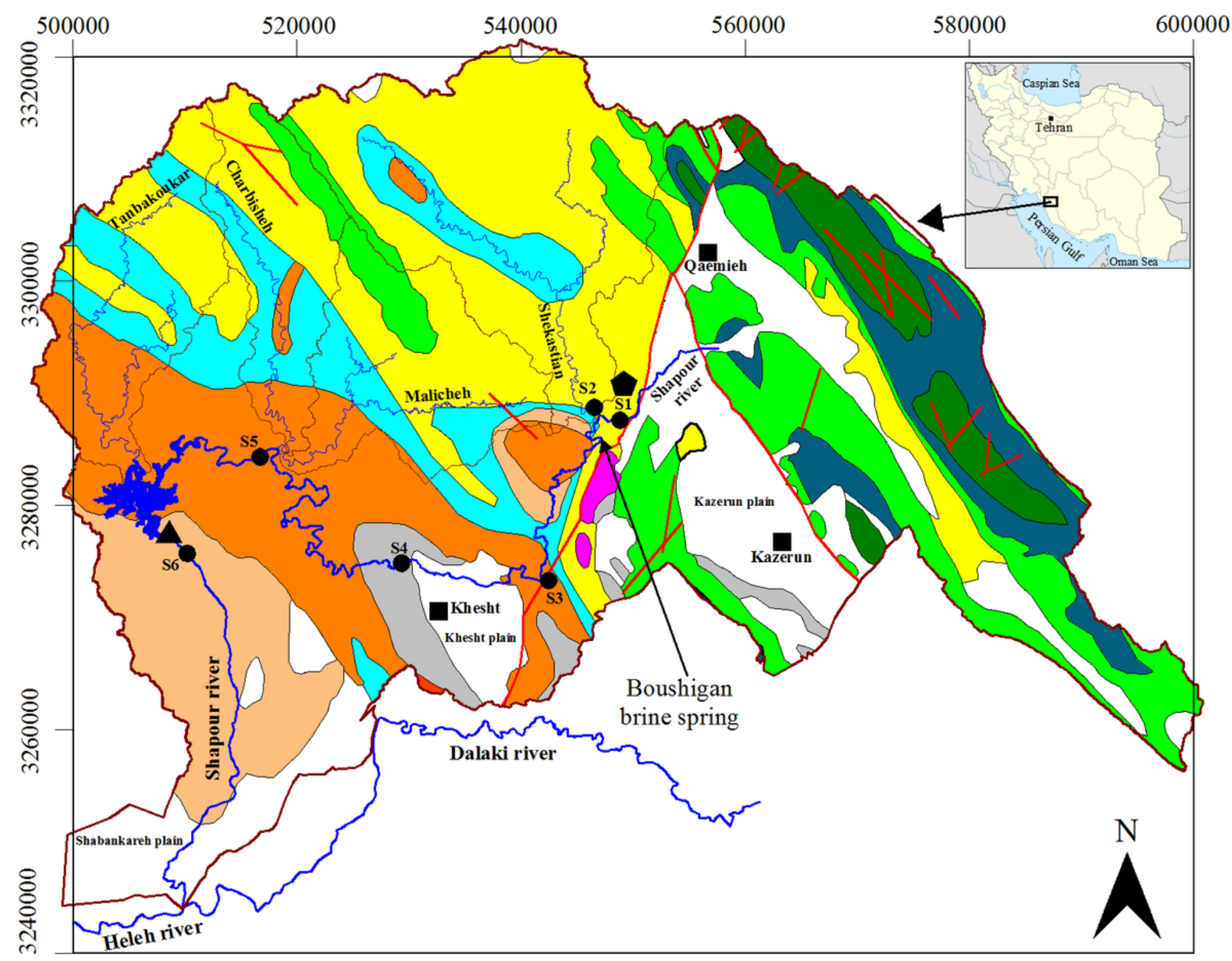

Geology legend and symnols

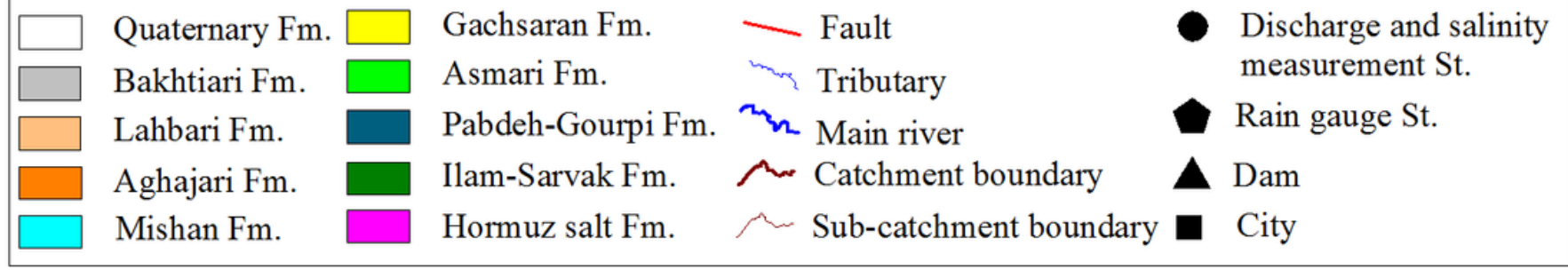

\section{Figure 1}

Situation and geology map of the Shapour river catchment and location of the measurement stations Note: The designations employed and the presentation of the material on this map do not imply the expression of any opinion whatsoever on the part of Research Square concerning the legal status of any country, territory, city or area or of its authorities, or concerning the delimitation of its frontiers or boundaries. This map has been provided by the authors. 


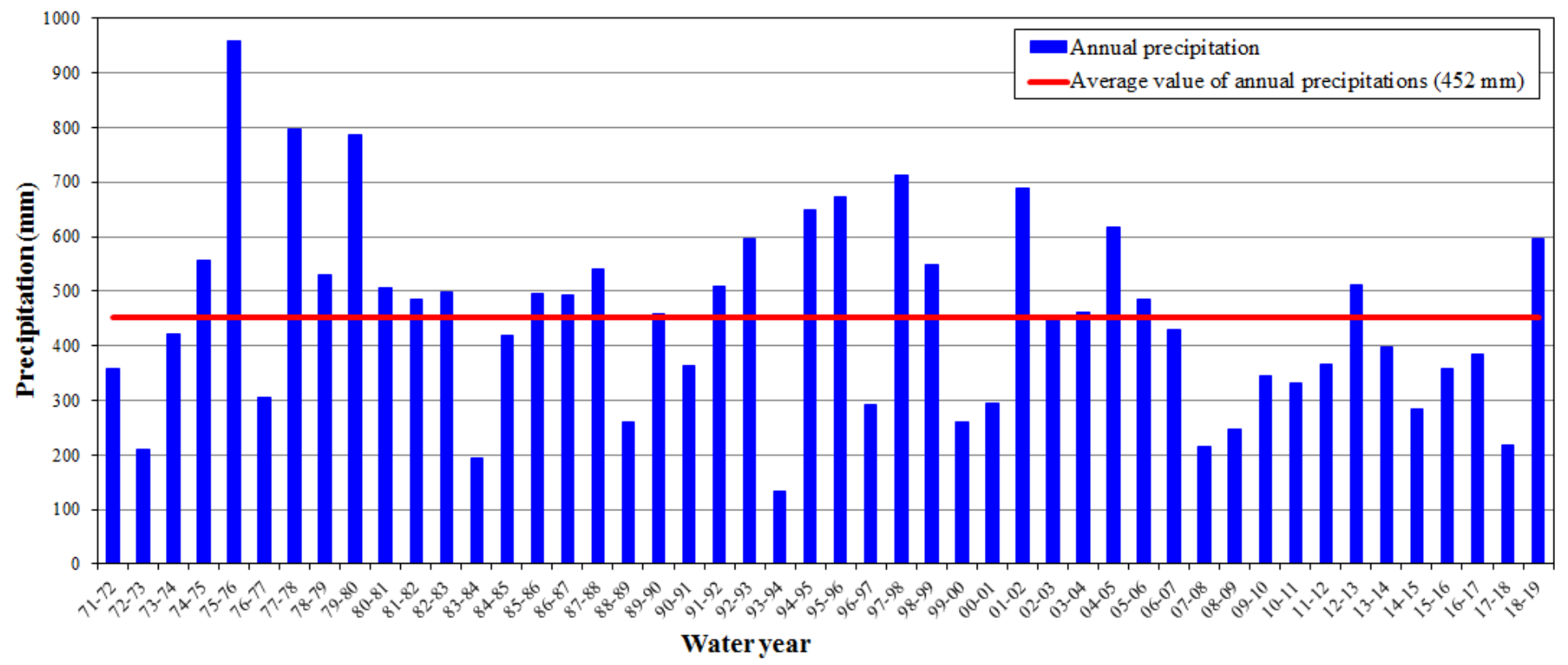

Figure 2

Variation of annual precipitation values in the study area 

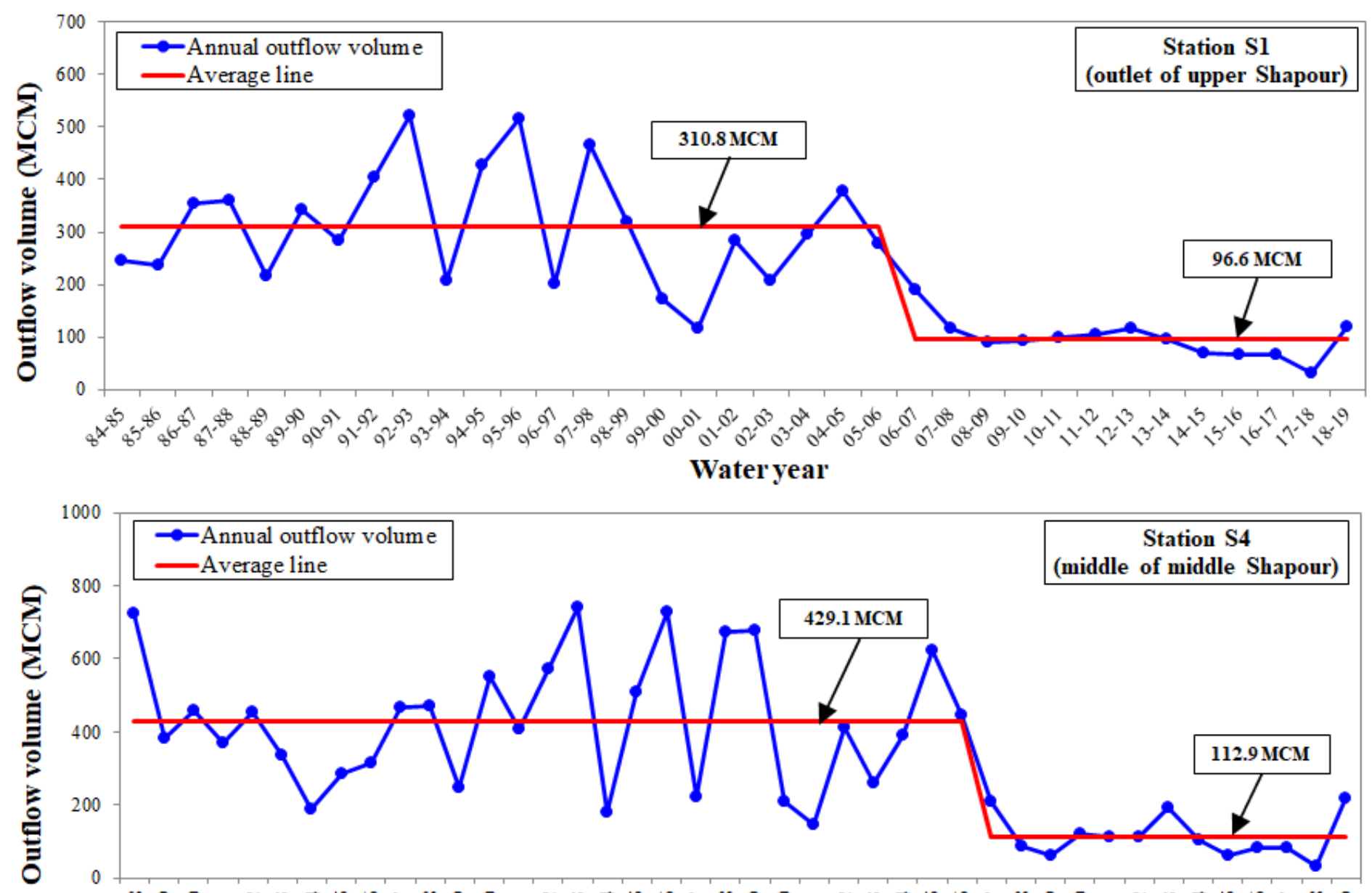

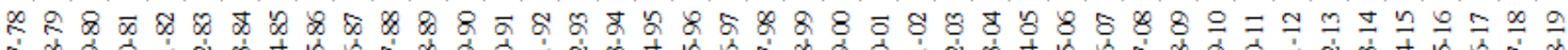

얐 Water year

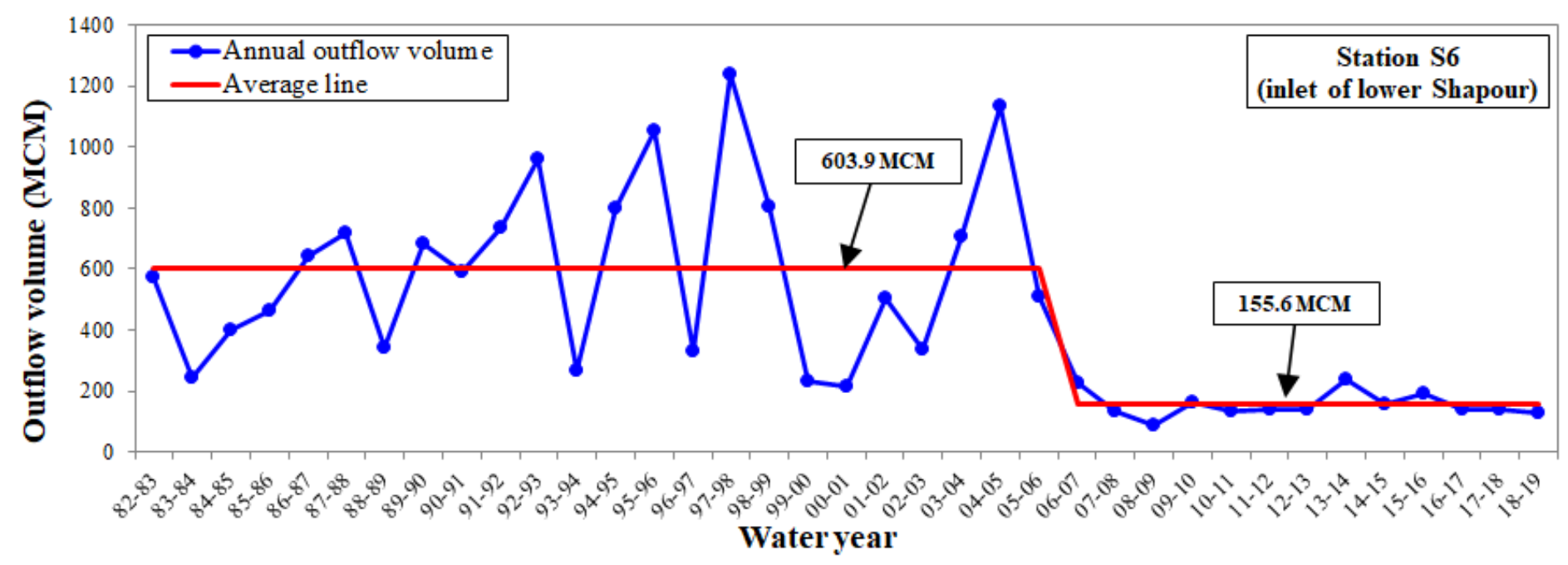

Figure 3

Variation in annual and average annual outflow volume in three hydrometric stations along the Shapour river 


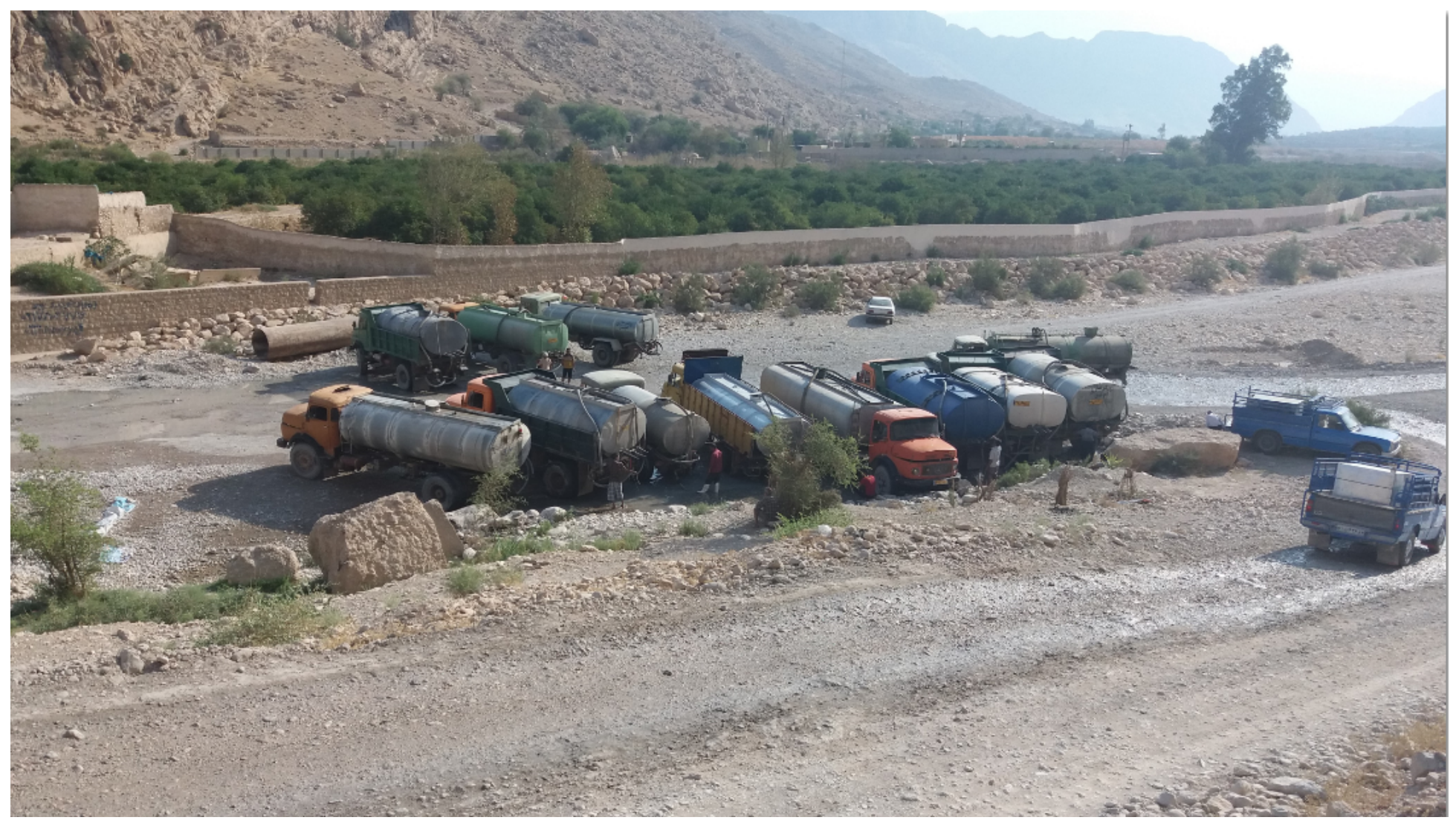

\section{Figure 4}

Image of extensive water removal from the upstream Shapour river (Sasan spring) by water trucks (image taken on 5-August-2018) 

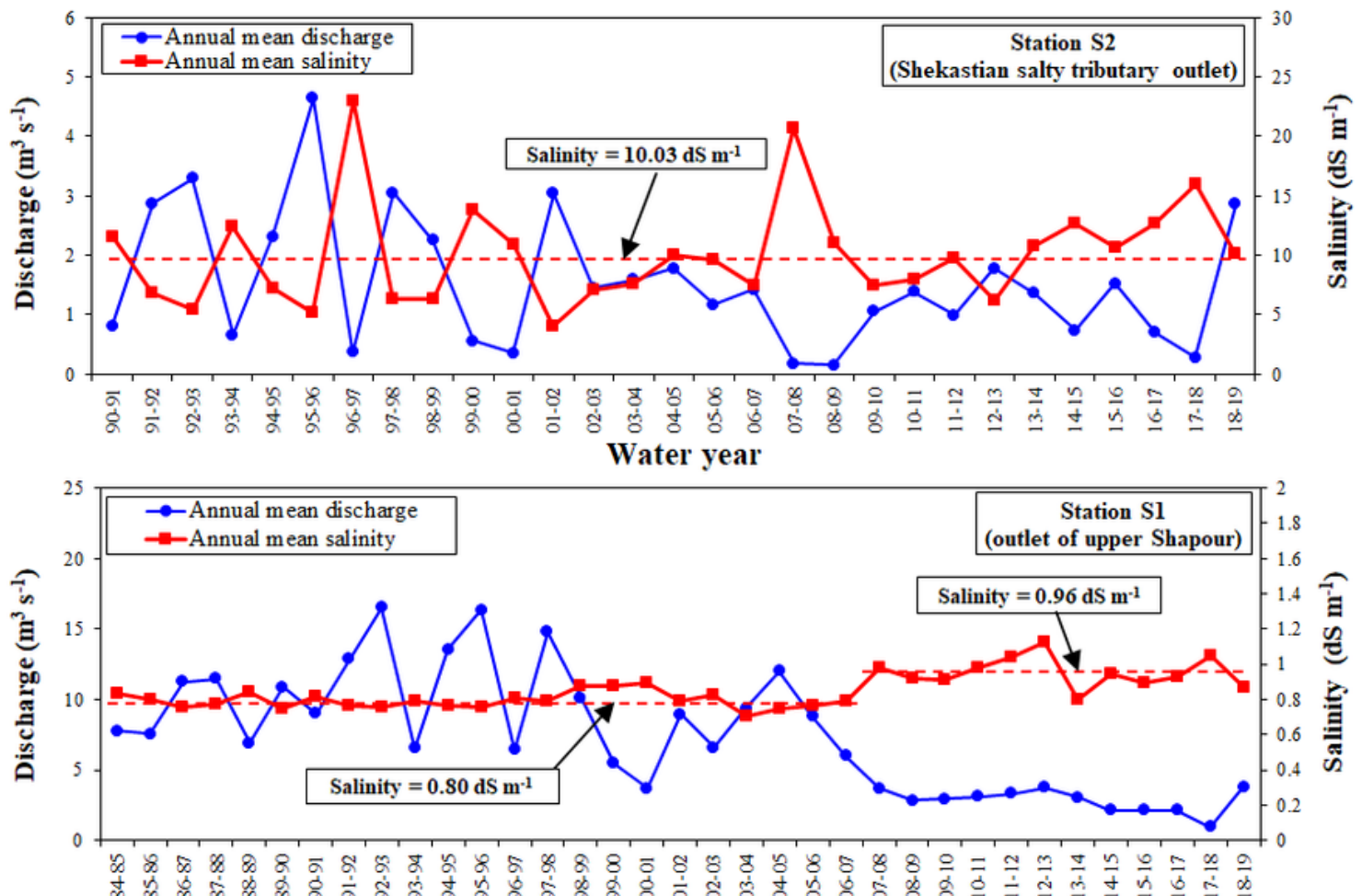

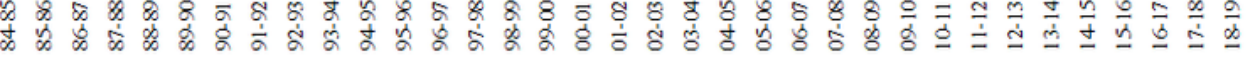

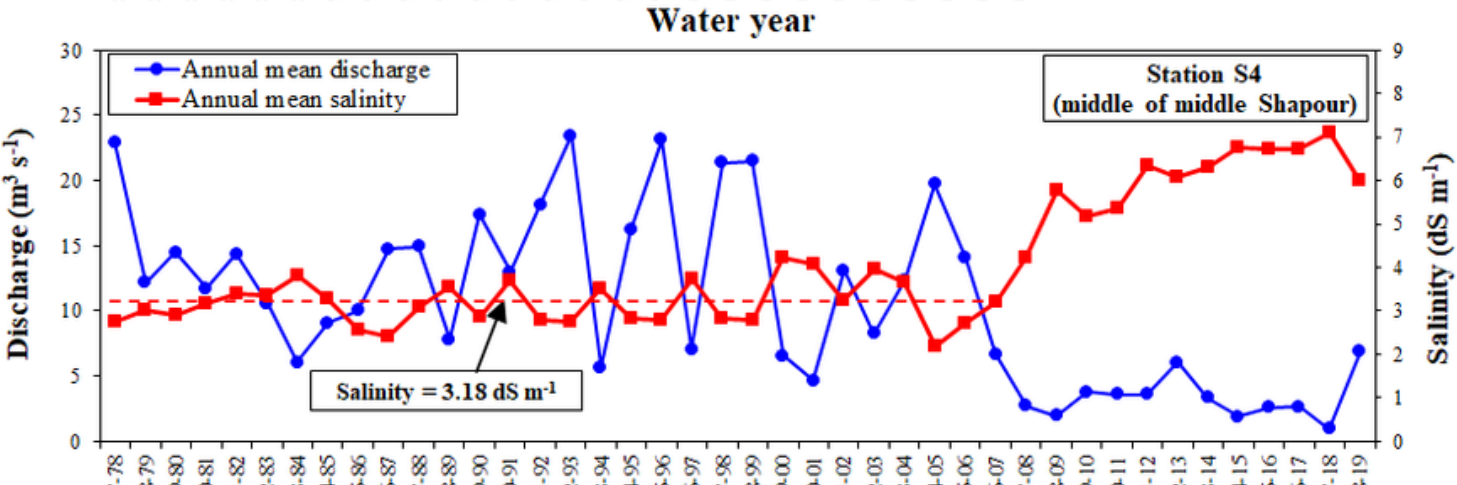

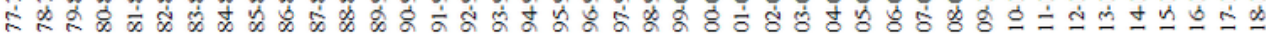

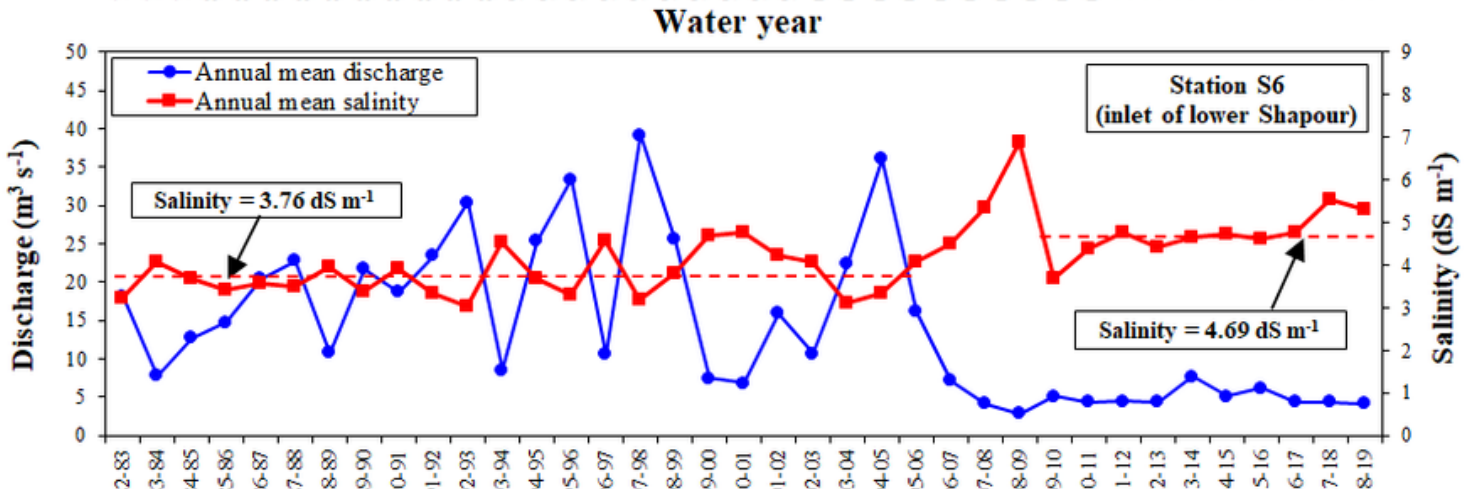

ळ

Water year

\section{Figure 5}

Variation in annual mean discharge and salinity at the hydrometric stations in the Shapour river catchment 

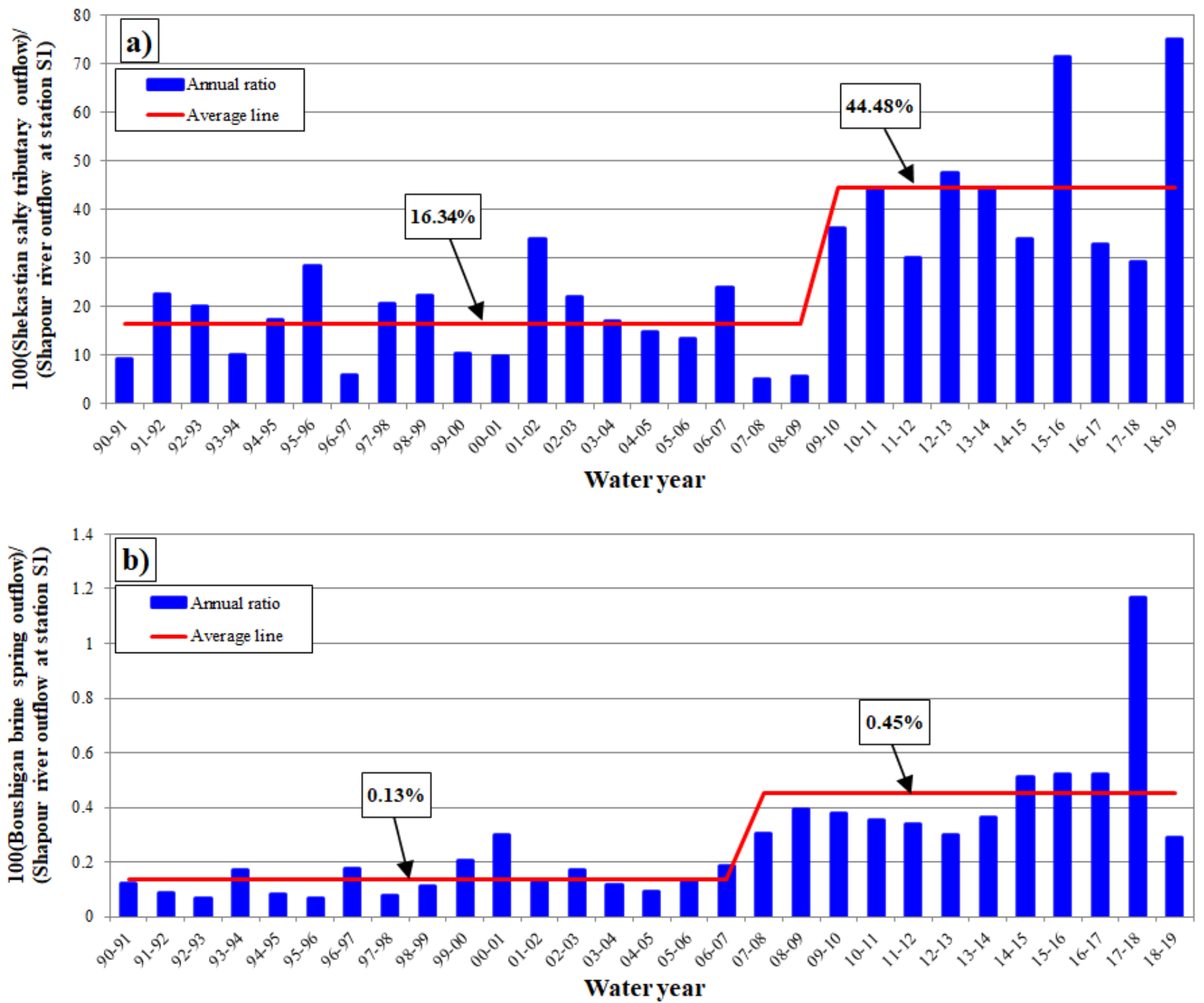

Figure 6

Annual variation in quota of Shekastian salty tributary and Boushigan brine spring from the Shapour river flow a) Ratio of salty-outflow from Shakastian tributary to fresh-outflow from the Shapour river at station S1 b) Ratio of brine-outflow from Boushigan spring to fresh-outflow from the Shapour river at station S1 


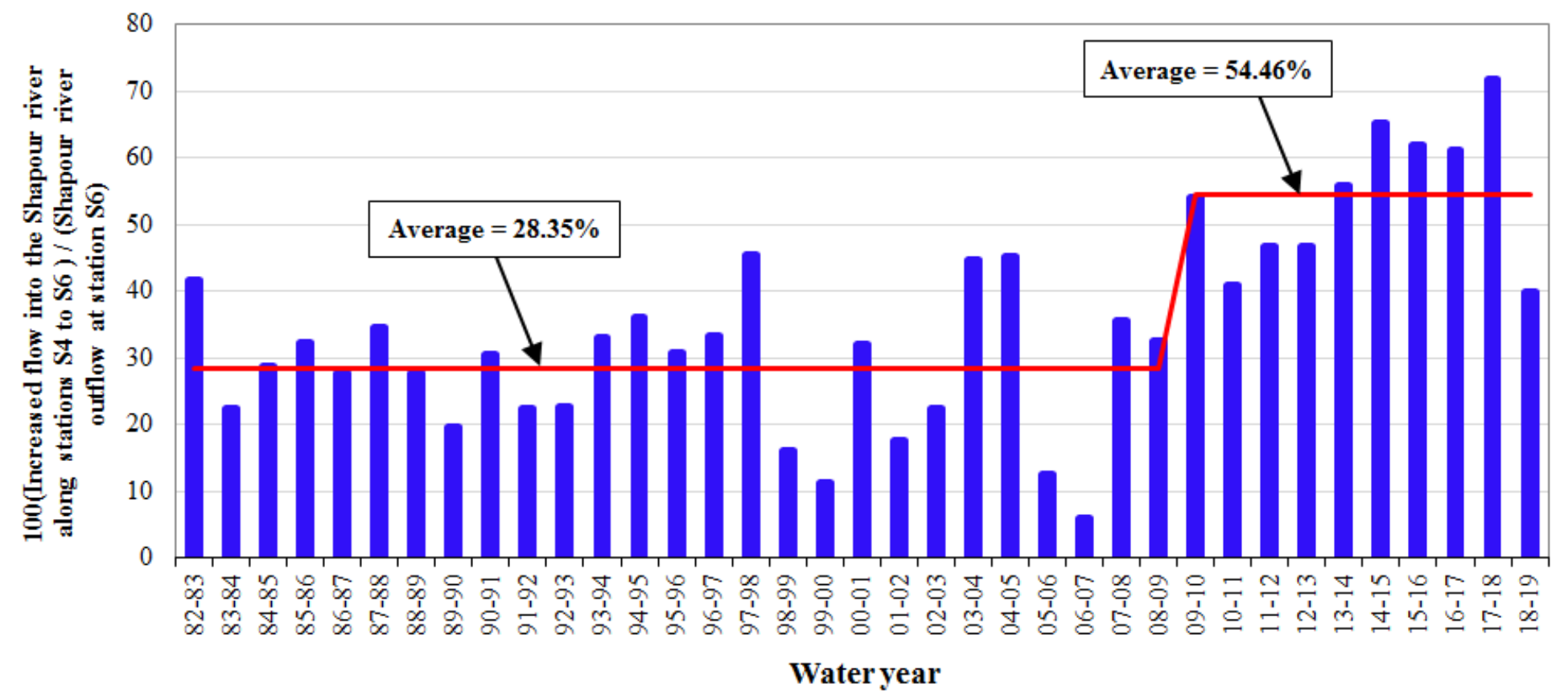

Figure 7

Annual variation in the ratio of the increased water into the Shapour river from water resources between stations S4 and S6 to the Shapour river outflow at station S6

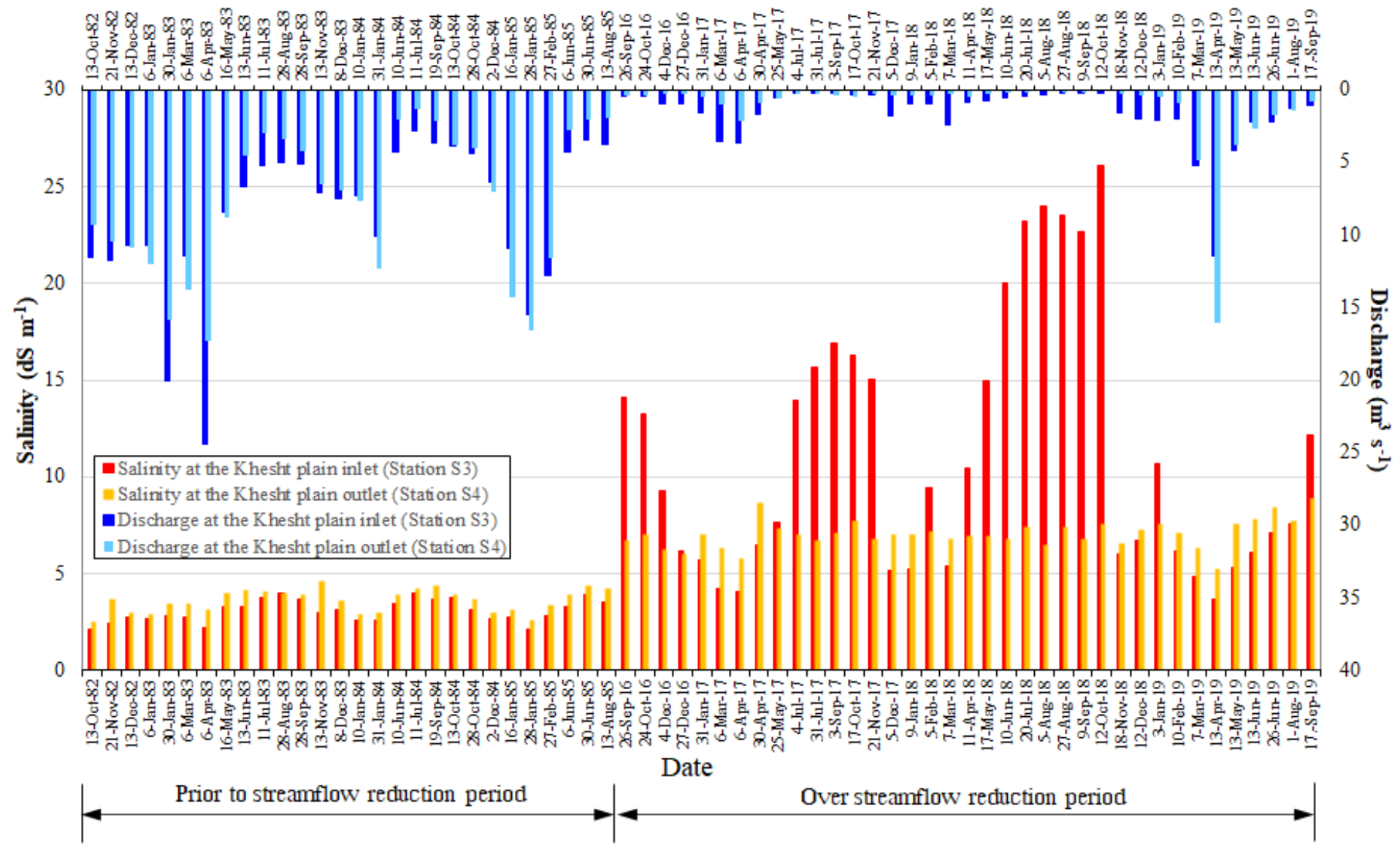

Figure 8 
The Shapour river discharge and salinity fluctuation at the Khesht plain inlet and outlet (stations S3 and S4) for 1982-1985 (prior to streamflow reduction period) and 2016-2019 (over streamflow reduction period)

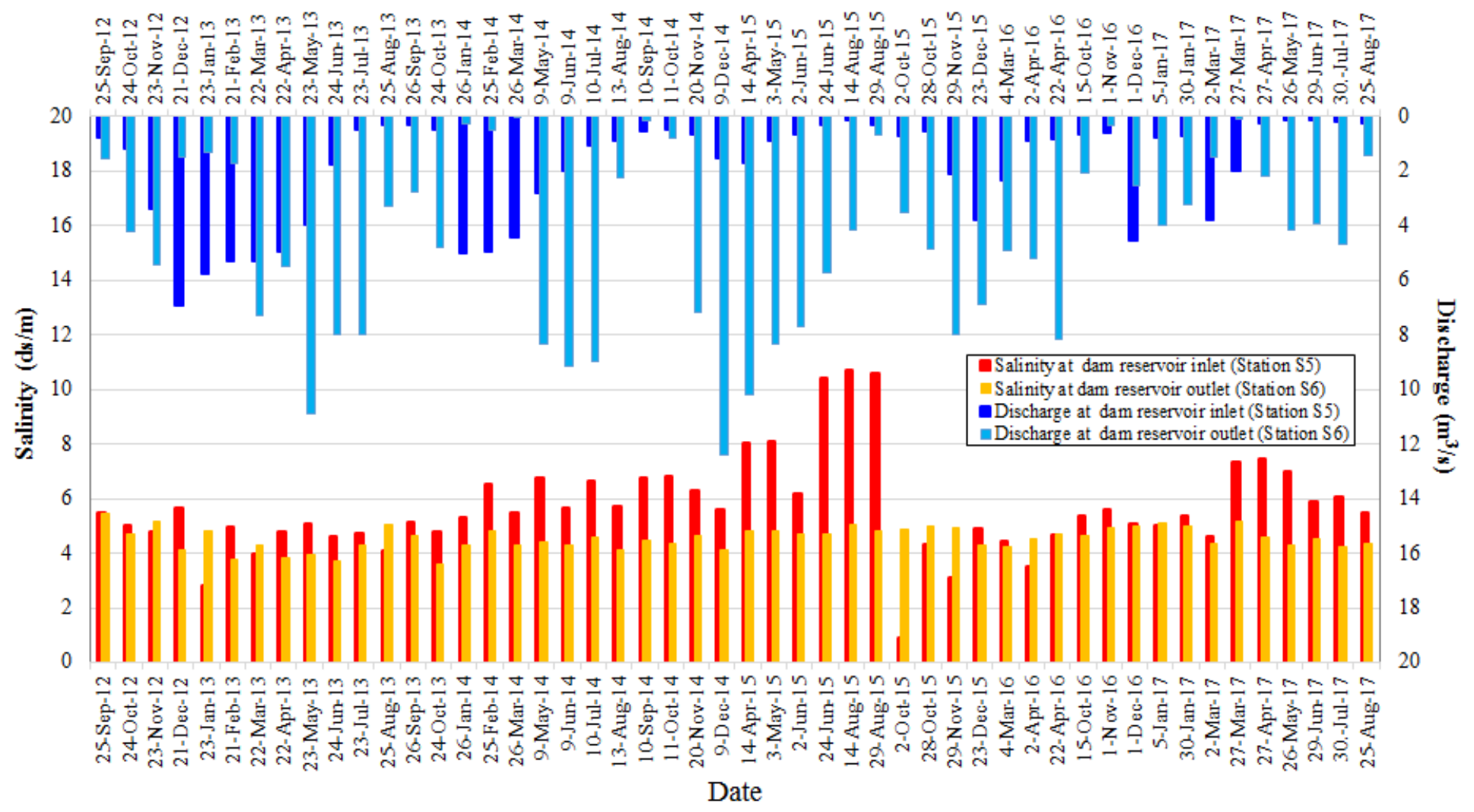

\section{Figure 9}

Salinity and discharge fluctuation of the Shapour river at inlet and outlet of the Raeisali-Delvari reservoir Salinity $\left(\mathrm{ds} \mathrm{m}^{-1}\right)$

Temprature $\left({ }^{\circ} \mathrm{C}\right)$
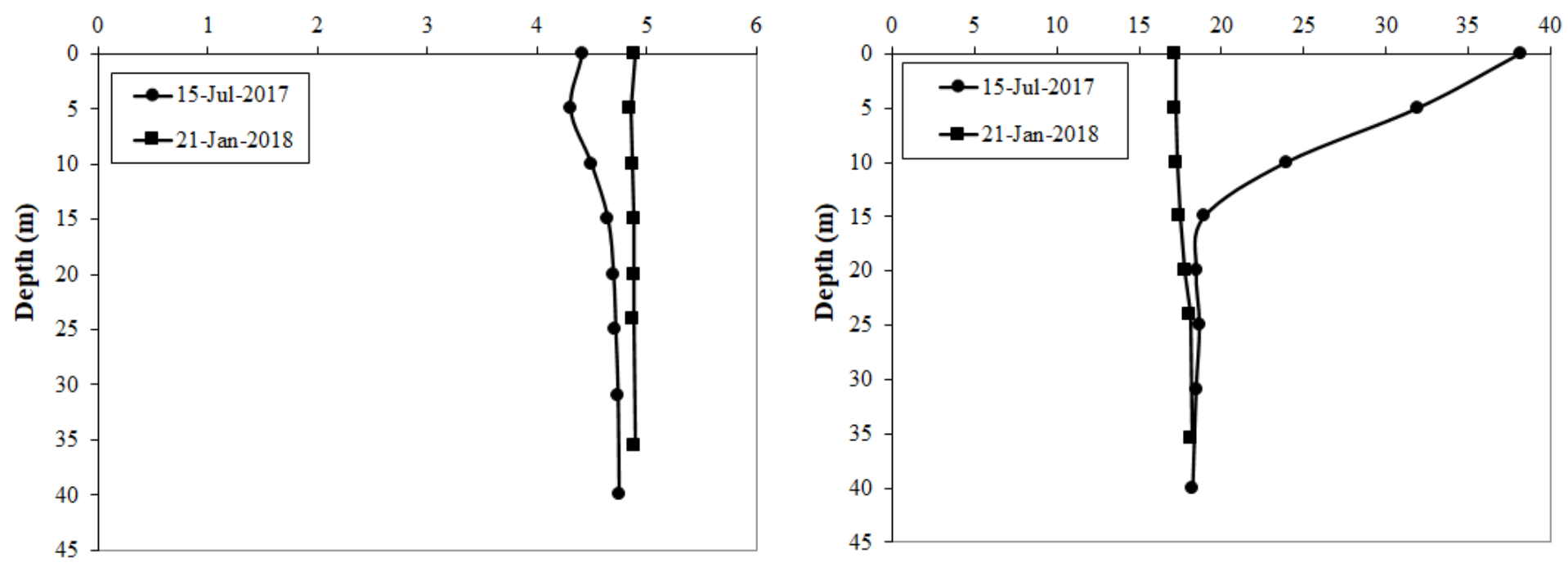

Figure 10 
Vertical variations in measured temperature and salinity of stored water in Raeisali-Delvari reservoir at 15Jul-2017 and 21-Jan-2018

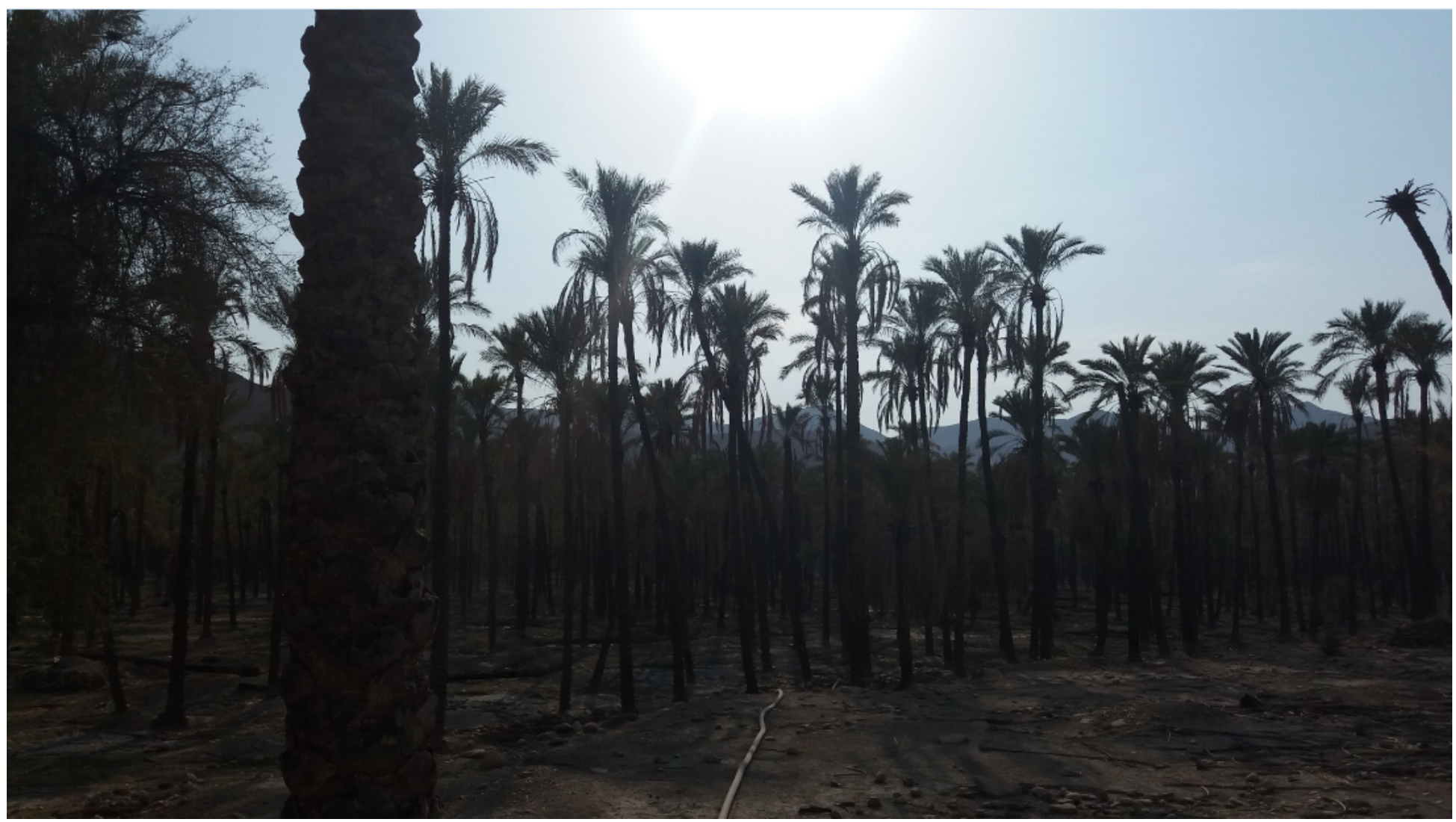

\section{Figure 11}

An image of the abandoned date orchards in the Khesht plain due to salinity rising of the Shapour river (image was taken at 5-August-2018)
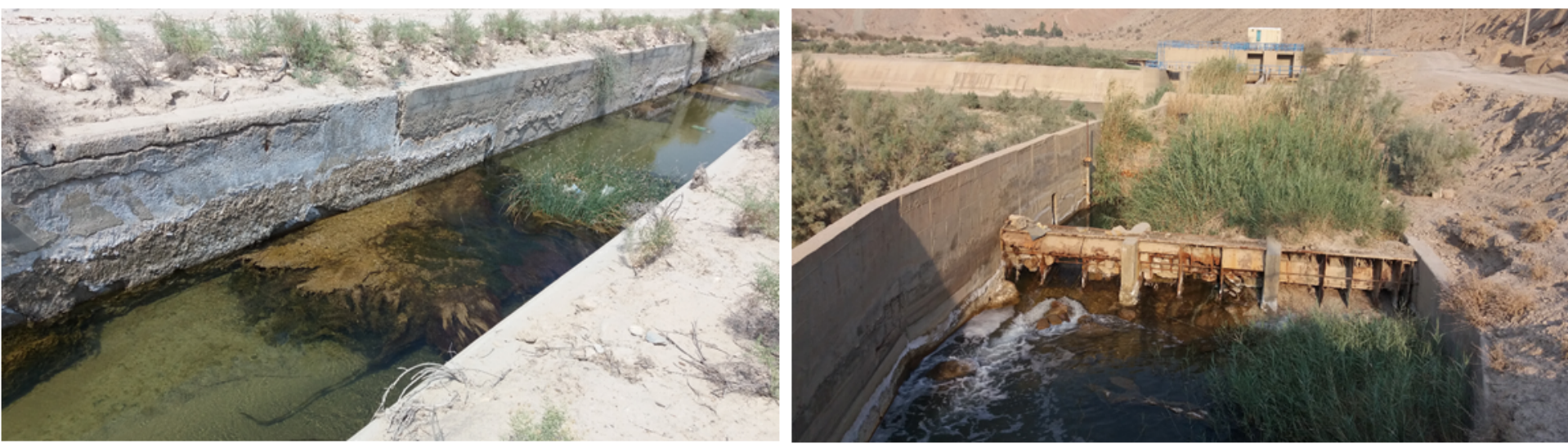

\section{Figure 12}

Images of corrosion and destruction of the Shapour river diversion and distribution facilities in the Khesht plain due to salinity rising of the Shapour river (image was taken at 5-August-2018) 